\title{
Biodiesel Waste Cooking Oil is Environmentally Friendly Alternative Fuels and More Feasible than Fossil Fuels
}

\author{
Hadi Prasutiyon ${ }^{1}$, Aguk Zuhdi Muhammad Fatallah ${ }^{2}$
}

(Received: 25 April 2020 / Revised: 11 August 2020 / Accepted: 31 August 2020)

\begin{abstract}
- the use of diesel engines is increasing at the moment, the other hand, supplies of petroleum base diesel oil in the market decreasing. Therefore we need alternative fuels to use as supplement fuel for diesel engines. Biodiesel processing can be done with the process of esterification and transesterification. Biodiesel is processed from used cooking oil can be done only by the transesterification process. Ester transesterification is the process of converting into esters in another form by reacting carboxylic esters and alcohols with an alkaline catalyst $(\mathrm{NaOH})$, in processing biodiesel transesterification process is the process of converting triglycerides of cooking oil into methyl or ethyl ester as biodiesel. According to various studies, biodiesel derived from waste cooking oil proved to be more environmentally friendly fuels than the results are known and used today. Nitrogen Monoxide emission levels (NOx) in the biodiesel from used cooking oil to produce emissions 12\% lower than emissions produced by diesel oil. Another advantage, the exhaust emissions of the unburned form of carbohydrates produced biodiesel used cooking oil turned out to be $25 \%$ lower than on diesel oil. The diesel engine durability test, performance analysis, analysis of the degree of damage is indicated by the metal content in lubricants, and test the properties of each lubricating it can be some conclusions as follows.
\end{abstract}

Keywords— biodiesel, durability, emissions. Waste cooking oil methyl ester, performance.

\section{INTRODUCTION}

B iodiesel as alternative fuels: the fuel-air mixture in a diesel engine is not homogeneous so that combustion takes place that a lot of the combustion chamber. In place of the local rich mixture, combustion will produce black smoke. This is the main problem of the diesel engine that uses conventional fuels. Various studies have been done to look for alternative fuels that are environmentally friendly [1]. Fuel gas (LNG and LPG), alcohol (methanol and ethanol), and vegetable oils have been a lot of attention and consideration as an alternative fuel that is cleaner environment [1][9]. The content of oxygen contained in the fuel greatly affects black smoke emissions reduction in diesel engine [1][30]. Alternative fuels that will be reviewed are vegetable oils are processed cooking oil (refined bleached and deodorized palm oil, RBDPO), and used cooking oil into biodiesel. Biodiesel, the methyl ester or ethyl ester, has excellent properties as a substitute for conventional diesel fuels, such as Cetane Number of 50 to 52, a low sulfur content, the oxygen content, Viscosity low enough, high enough calorific value [1].

Biodiesel processing can be done with the process of esterification and transesterification. Biodiesel is processed from used cooking oil can be done only by the transesterification process [1].

Esterification is the process of making esters of carbohydrates and alcohol with an acid catalyst (H2SO4). Ester is a carboxylic acid derivative of the

Hadi Prasutiyon, Department of Marine Engineering and Marine Science, Hang Tuah University, Surabaya 60111, Indonesia. E-mail: hadi.prasutiyon@hangtuah.ac.id

Aguk Zuhdi MF, Department of Marine Engineering, Institut Teknologi Sepuluh November, Surabaya, 60111, Indonesia. E-mail: fathalaz@its.ac.id
carboxylic-OH group is replaced by or groups of the alcohol [9]. The ester can make a hydrogen bond with water, so the water must be removed biodiesel processing. Low molecular weight esters slightly soluble in water, but ester consisting of four or five carbon is almost insoluble in water [1].

Ester transesterification is the process of converting into esters in another form by reacting carboxylic esters and alcohols with an alkaline catalyst $(\mathrm{NaOH})$, in processing biodiesel transesterification process is the processing of converting triglycerides of cooking oil into methyl or ethyl ester as biodiesel [1][9].

In fact, to produce biodiesel that is of better quality and has characteristics similar to diesel fuel, it must meet the requirements of SNI 04-7182-2006 [1][9][35]. Wang [9] has synthesized biodiesel using a two-stage catalysis process, as described above. Buchori [35] suggests producing biodiesel with a non-catalytic cracking process takes place at high temperatures and pressures, thus requiring greater energy.

In order to produce high-quality biodiesel, an appropriate pre-treatment is needed before transesterification is carried out by Gerpen [1]. Free fatty acids contained in biodiesel is the cause due to the formation of soap so that damage to the oil. One way to eliminate the sources that cause oil damage is to use microfiltration technology. [1][35].

Microfiltration aims to reduce or eliminate suspended solids and organic compounds such as proteins, carbohydrates, and free fatty acids [35]. Biodiesel fuel is an alternative renewable fuel for diesel fuel that is produced from different kinds of vegetable oils. As a renewable fuel, biodiesel can be used in diesel engines without significant modification [9][36].

This process takes place at low temperature and pressure $\left(150^{\circ} \mathrm{F}\right.$ and 20 Psia) with a base catalyst $(\mathrm{NaOH}$ or $\mathrm{KOH})$, producing a $98 \%$ biodiesel and glycerol [1]. Biodiesel produced from cooking oil methyl 
ester with the fatty acid composition of the dominant is shown in table 1 [1].

TABLE 1.

THE CHEMICAL FORMULA OF THE PREDOMINANT FATTY ACID METHYL ESTER BIODIESEL

\begin{tabular}{cc}
\hline Fatty Ac & Formula \\
\hline Laurat & $\left.\mathrm{CH}_{3}\left[\mathrm{CH}_{2}\right]\right]_{0} \mathrm{COOCH}_{3}$ \\
Palmitat & $\mathrm{CH}_{3}\left[\mathrm{CH}_{2}\right] 14 \mathrm{COOCH}_{3}$ \\
Stearat & $\mathrm{CH}_{3}\left[\mathrm{CH}_{2}\right], 6 \mathrm{COOCH}_{3}$ \\
Oleat & $\mathrm{CH}_{3}\left[\mathrm{CH}_{2}\right]_{7} \mathrm{CH}_{2}\left[\mathrm{CH}_{2}\right] 7 \mathrm{COOCH}_{3}$ \\
Linoleat & $\mathrm{CH}_{3}\left[\mathrm{CH}_{2}\right]_{4} \mathrm{CH}=\mathrm{CHCH}_{2} \mathrm{CH}=\mathrm{CH}\left[\mathrm{CH}_{2}\right]_{7} \mathrm{C}$ \\
& $\mathrm{OOCH}_{3}$ \\
\hline
\end{tabular}

The composition of methyl ester affects the physical and chemical properties of biodiesel. CPO for biodieselpredominant fatty acid is oleic and palmitic, whereas biodiesel-RBDPO dominant fatty acids are linoleic and oleic. The physical properties of methyl ester biodiesel Tabel 2 [1].
Lauric fatty acid, palmitic, and stearic are fat at ambient conditions, whereas oleic and linoleic nature as oil. Differences in the composition of fatty acids are fats and oils of biodiesel would affect a large viscosity. The more fatty acid content that is as fat in biodiesel, the greater the Viscosity and vice versa. The more fatty acids that are a little more oil prices in biodiesel viscosity [1]

TABLE 2.

PHYSICAL ATTRIBUTES OF METHYL ESTER BIODIESEL AND DIESEL.

\begin{tabular}{llll}
\hline \multicolumn{1}{c}{ Qualities } & \multicolumn{1}{c}{ Bio-RBDPO } & \multicolumn{1}{c}{ Bio CPO } & \multicolumn{1}{c}{ Diesel Fuel } \\
\hline The calorific value LHV (kJ/kg) & $367.764,83$ & $37.114,13$ & $40.297,32$ \\
Specific Gravity (gr/cm3) & 0,869 & 0,870 & 0,857 \\
Kinematic Viscosity (cSt) & 6,04 & 6,72 & 5,16 \\
Cetane Number & 55 & 60 & 45
\end{tabular}

The number of carbon double bonds $(\mathrm{C}=\mathrm{C})$ and $\mathrm{C}-\mathrm{H}$ bond in the fatty acid will affect the heating value and cetane number of biodiesel. The bonds energy dissociation of the $\mathrm{C}=\mathrm{C}$ is $157 \mathrm{kcal} / \mathrm{mol}$, and $\mathrm{C}-\mathrm{H}$ is equal to $94 \mathrm{kcal} / \mathrm{mol}$, the $\mathrm{C}=\mathrm{C}$ bonds will be reduced by two $\mathrm{C}-\mathrm{H}$ bonds so that the bonds energy dissociation of the $\mathrm{C}=\mathrm{C}$ bonds is smaller than the bonds energy dissociation two $\mathrm{C}-\mathrm{H}$ bonds. Many fatty acids having a $\mathrm{C}=\mathrm{C}$ bonds in biodiesel will reduce the heating value of biodiesel [1].

Diesel engine applied to many areas due to high efficiency and durability, confidence (reliability) is better when compared to several other prime movers [2].[3]. On the other hand, with a variety of advantages, diesel engines that use conventional fuels, also known as a producer of high air pollution as well. Fossil fuel supplies are very limited. For this reason, from now on, it should begin thinking of looking for alternative fuels as a substitute for petroleum fuels [3][5].

The most common scientific sense of the term biodiesel fuel made from biological resources, or biomass [3], but biodiesel also have a composition that consists of alkyl esters of fatty acids [6].
Biodiesel is produced from oils/fats of vegetable or animal origin. Biodiesel is used as a substitute for diesel fuel for a diesel engine. Biodiesel is used as a substitute for diesel fuel for a diesel engine. Biodiesel is widely used in the industry. The advantages of using biodiesel include: the availability of raw materials is continuous, environmentally friendly, low sulfur content, and can reduce exhaust emissions [4][10]. Biodiesel can be made from a variety of sources, such as vegetable oils, animal fats, and waste oils or fats (egg leftover frying oil). Biodiesel can be produced from plant oils [5], such as coconut oil, castor oil, palm oil [7][10], and used cooking oil [8].

Biodiesel is fuel from vegetable oil that has characteristics resembling diesel oil or diesel fuel of petrodiesel. Biofuels are all fuel derived from vegetable oils. Therefore, biofuel can be biodiesel, bioethanol, and bio-oil (pure vegetable oil). Biodiesel is an ester of vegetable oil form after a change in chemical properties because of the transesterification process that requires additional methanol [3][8]. Table 3 below shows the physical and chemical properties of biodiesel according to SNI standards [3]. 
TABLE 3.

CHARACTERISTICS OF BIODIESEL ACCORDING TO SNI STANDARDS

\begin{tabular}{ccc}
\hline Characteristics & Unit & Value \\
\hline Cetane number & & $\min 51$ \\
Density & $\mathrm{Kg} / \mathrm{m}^{\mathrm{J}}$ & $850-890$ \\
kinematic viscosity & $\mathrm{mm}^{2} / \mathrm{s}(\mathrm{cSt})$ & $2.3-6$ \\
Flashpoint & ${ }^{\mathrm{U}}$ & $\min 100$ \\
Cloud point & ${ }^{\mathrm{u}} \mathrm{c}$ & $\operatorname{max~} 18$ \\
Pour point & ${ }^{\circ} \mathrm{c}$ & $\operatorname{max~} 18$ \\
The water content & $\%-$ volume & $\max 0.05$ \\
free glycerol & $\%-$ mass & $\max 0.02$ \\
glycerol total & $\%-$ mass & $\max 0.24$ \\
Total Acid number & $\mathrm{mg} \mathrm{KOH} / \mathrm{gr}$ & $\max 0.8$ \\
Strong Acid number & $\mathrm{mg} \mathrm{KOH} / \mathrm{gr}$ & - \\
Ester content & $\%-$ mass & $\min 96.5$ \\
\hline
\end{tabular}

Biodiesel characteristics: as of biodiesel fuel must meet ASTM requirements set. There is some literature that outlines the properties of biodiesel. Among other things in the report, Connemann \& Fischer [9] and Steven A 10]. Howel, BS one important parameter in determining the quality of the fuel is the cetane number. Cetane number is a measure used to express the quality of fuel combustion in the engine combustion chamber. Cetane number is a function of the number of $\mathrm{CH}$ and $\mathrm{CH}$ in fuel composition [3].

\section{METHOD}

This paper is the result of a review of a number of recommended journals discussing biodiesel both in terms of the technical process of making biodiesel as an alternative fuel and the impact of engine use both on performance, combustion process, durability, as well as exhaust gas and emission. This paper tells how biodiesel is expected to become fuel in the future. We will present comparative studies and some research here.

A comparison of biodiesel fuel energy with power generated by a diesel engine that uses biodiesel fuel is higher than the ratio of diesel fuel energy to power it produces [20]. This relates to the calorific value of the biodiesel fuel mixture that is greater than solar. Even if the terms of calorific value, the difference in thermal efficiency is also greatly influenced by the ignition delay time, peak temperature, pressure, and further combustion period of combustion [3],[20]. Where in theory, advanced combustion time (after burning) the longer will decrease the thermal efficiency of the combustion process. It could be time difference after burning factors that cause differences in the thermal efficiency of the use of each fuel [3]. However, because the study was not able to show graphic characteristics of the combustion of each fuel, which cannot be explained with certainty, the cause of differences in the thermal efficiency of the use of some of the biodiesel fuel mixture. It's just that it can be seen that the difference in thermal efficiency is not only influenced by the calorific value of the fuel, will also be influenced by other factors, such as cetane number, flash point, and Viscosity of the fuel. Where the totality of the factors that affect the combustion characteristics of each fuel, so the difference is burning to affect the thermal efficiency [3][20].
Biodiesel Waste cooking oil Methyl Ester (JME): Waste cooking oil, the rest of the pan can't be used, should be discarded. This will impact the rest of the frying pan to the environment if not treated properly. Useless leftover frying can be used as bio-diesel. Biodiesel can be either used as a complement diesel oil (gas oil) as a diesel engine. The results showed that various mixtures of methyl ester of

waste cooking oil with diesel oil do not degrade engine performance significantly [11]. Biodiesel transesterification process of oil waste cooking oil in general, starting with adding methoxide (methanol solution of $20 \%$ of the volume of the oil with $\mathrm{KOH} 3.5 \mathrm{~g}$ / $100 \mathrm{ml}$ of methanol) [3]. This process is done by the treatment of heating for approximately 60 minutes. The subsequent deposition of glycerine after less than a day. Precipitated glycerine is separated by methyl ester biodiesel and then washing with distilled water. Making the fuel is done several times with different compositions to obtain the results of biodiesel that meets ISO standards 04-7182-2006. Of the methyl ester transesterification process, results produced an average of $82 \%$ and $11 \%$ glycerine [12].

Use of Mixed Waste cooking oil Methyl Esther (JME) and diesel in the ratio 10:90 increase the effective power diesel engine when compared with pure diesel fuel at a certain rpm and load. The increase also occurred in a mixture of 20:80 and 30:70. Even with the fuel composition JME $100 \%$ at $2000 \mathrm{rpm}$ rotation, an increase in the effective power of $30.34 \%$ when compared to using diesel fuel. JME will be promoted as a substitute for diesel fuel and then be widely used as a fuel in the future [13]. JME has a viscosity and density are still within the allowable limit as diesel engine fuel, at room temperature, viscosity kinematic $7: 5 \mathrm{cSt}$ is higher than diesel oil, and its density $895.3 \mathrm{~kg} / \mathrm{m} 3$ is greater than petroleum diesel and has a cetane number higher than solar thus affecting the combustion process. JME was mixing diesel oil with a resulting effect on power and specific fuel consumption of the diesel engine when compared to using diesel oil. The power generated fatherly JME 10, JME 20, JME 30 tends to increase in 2000 and 2400 rounds [13]. In the study, the pretreatment process (esterification) carried on used cooking 
oil can lower free fatty acid content of $2.5 \%$ to $1.1 \%$.

The results of the analysis of the physical and chemical properties of biodiesel can be seen in table 4 [14].

TABLE 4.

PHYSICAL AND CHEMICAL PROPERTIES OF USED COOKING OIL BIODIESEL SYNTHESIS RESULT

\begin{tabular}{ccc}
\hline Physical and Chemical Properties & Biodiesel & SNI Biodiesel \\
\hline Density $40^{\mathrm{U}} \mathrm{C} . \mathrm{Kg} / \mathrm{L}$ & 850 & $850-890$ \\
Viscosity kinematic $\left(40^{\mathrm{U}} \mathrm{C}\right) . \mathrm{cSt}$ & 3.2 & $2.3-6$ \\
Numbers Acid. $\mathrm{Mg} \mathrm{KOH} / \mathrm{g}$ & 0.5 & Max. 0.8 \\
Water content. \% vol & 0.02 & Max. 0.05 \\
Flashpoint. ${ }^{\circ} \mathrm{C}$ & 176 & Min. 100 \\
Pour point. $^{\mathrm{U}} \mathrm{C}$ & 9 & - \\
Fog point. $^{\circ} \mathrm{C}$ & 14.6 & Max. 18 \\
Cetana Index & - & - \\
\hline
\end{tabular}

In producing biodiesel does not always get the results of the same product; according to the method that has been planned that the results of biodiesel will vary with the amount of production. Each production composition of a biodiesel product is always recorded, and the results are observed from the production and physical and visual characteristics of the species. Based on the experience of esters formed, color is closely associated with the density, Viscosity, and the amount of glycerol produced [3][21].

Cooking methyl ester is made through the process of transesterification reaction from used cooking oil. Used cooking oil, which is used in crackers, is frying up several times. The transesterification reaction is often called alcoholysis reaction; the reaction between triglycerides with alcohol will produce esters and glycerine [21]. Alcohol is used as a reactant in this reaction is methanol [3]. In the transesterification, the reaction catalyst is added to accelerate the reaction rate and improve result reaction products. The catalyst used for this reaction is a base catalyst in the form of potassium hydroxide $(\mathrm{KOH})$ [3] [25].

This study conducted a few experiments on the transesterification reaction. The experiments were performed by varying the amount of methanol and catalyst used. The amount of methanol used was $10 \% \mathrm{~s} /$ d $20 \%$ by weight of waste cooking oil. From several experiments, it was found that the amount of methanol which yield the most optimal cooking methyl ester is between $10 \% \mathrm{~s} / \mathrm{d} 15 \%$ by weight of waste cooking oil. While the catalyst added corresponding literature is \pm 1 $1.5 \%$ by weight of waste cooking oil [3][26].

The reaction process must be carried out in the container glass, enamel or stainless steel and may not use
Aluminum or plastic containers because it will affect the reaction. In this study, the reaction process using a glass container in the form of a beaker (beaker glass). The transesterification process is carried out with a reaction temperature of $55-58{ }^{\circ} \mathrm{C}$. The reaction temperature must be kept to no more than $60^{\circ} \mathrm{C}$ because, at that temperature, methanol has reached a boiling point. If the heating is carried reached a temperature of $60^{\circ} \mathrm{C}$, the methanol will evaporate. The transesterification reaction takes place within \pm 60 minutes. The solution was stirred continuously during the reaction process. At this stage, the resulting solution murky brownish-yellow [3],[27].

After the stirring process for \pm 60 minutes, the reaction product allowed to stand for 6-12 hours, to form two distinct layers, namely cooking methyl ester and glycerine. In the next stage, cooking methyl ester is separated from glycerine. Waste cooking oil methyl ester, which has been separated from the glycerine, is then washed using distilled water. The washing process is done by a bubbling method for \pm 60 minutes. Waste cooking oil methyl ester had been washed and then deposited for 12-24 hours. It will form two distinct layers, namely biodiesel and the wash water. The next step is separated from the water washing biodiesel. Next, do the drying process that aims to remove the water remaining in the biodiesel (methyl ester cooking). The drying process is done by heating the biodiesel up to a temperature above the boiling point of water, which is between $120^{\circ} \mathrm{C} \mathrm{s} / \mathrm{d} 130^{\circ} \mathrm{C}$. Wherein the drying process is done within 30-45 minutes [3][28].

The reaction process by using a composition ratio as in Figure 1, and the stages of the reaction process as described above, the transesterification reaction is performed to produce waste cooking oil methyl ester \pm $80-90 \%$ and $5-10 \%$ glycerine [3][29].

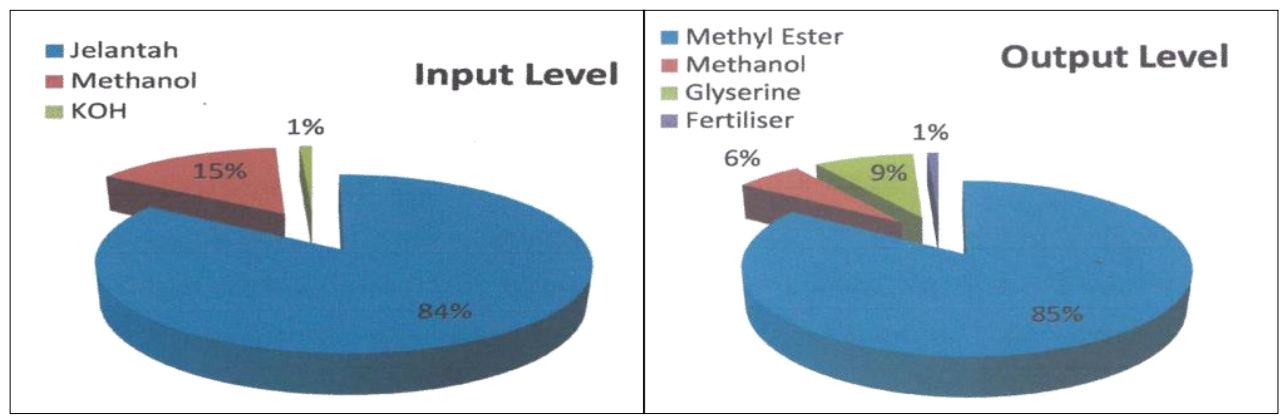


Figure. 1. Processing techniques to make Waste cooking oil Methyl Ester.

The blending of biodiesel becomes important to talk about because it has a lot of raw material for biodiesel are not similar. While each of the different raw materials has different characteristics so that if we want to mix two or more types of biodiesel may not be suitable or even not be mixed well. A good way to my study of the characteristics of biodiesel is the experiment has developed a biodiesel specification that will guarantee its performance regardless of where the source triliteral. During this time, the properties of biodiesel were always determined by chemical experiments [3][14]. However, it is possible to get the properties of biodiesel blend algebraically [3][14].

\section{RESULTS AND DISCUSSION}

Analysis of the performance (performance) of a diesel engine that is discussed in this study is the characteristics of the engine power, torque, fuel consumption, and thermal efficiency. Testing the performance of the diesel engine is done by using JME (cooking methyl ester) with some compositions that B10, $\mathrm{B} 20, \mathrm{~B} 50$, and B100 and also tested for comparison of pure diesel fuel [3],[15].

Diesel Engine Performance: In the spin machine that produces maximum power is almost no difference in power output between the two types of fuel, but there was a slight increase in power output by a diesel engine when using JME 50/50. Diesel engine, the power increase is not large around $0: 21 \%$ from solar power. While fuel consumption when engines use diesel has decreased by about $3.9 \%$ when engines use JME. But if the overall fuel consumption between the two is not much different, the average fuel consumption when the engine using JME better because it always under the line of the average - average when the engine using diesel fuel because the fuel injection is done in a certain amount, then weight differences will affect the kind of power that produced by machine due to differences in mass of the fuel is injected [16][13].

At the maximum torque, the engine produces more torque nice when using diesel as fuel. But when using fuel JME, decreased engine torque produced is equal to $8.8 \%$. The average black lines representing Peak Torque JME always under the red line represents the peak torque of a diesel, while their fuel consumption. The engine fuel use JME actually rose by $9 \%$ compared to the fuel consumption when the engine using pure diesel. The black line representing fuel SFOC JME always been above the average SFOC when the engine using diesel fuel, increased fuel consumption due to the Viscosity of JME and diesel fuel mixtures that are higher than the Viscosity of pure diesel. The Viscosity of the fuel is relatively high to make the fuel does not easily flow through the system pump and injection inserting fuel into combustion space, thus will affect the duration of injection and spray atomization [18][17]. That increased consumption is estimated by the number of unburned fuel. High Viscosity gives imperfections in the process of fuel atomization and evaporation. The abnormality in combustion also lowers the combustion temperature so as to counter the burden faced by the necessary ingredients fuels than more [13][15].

The performance of the diesel engine is directly related to the amount of heat given during combustion [23]. To fuel the heat value low required fuel more to generate power of one horsepower compared with the fuel heat value higher, or in other words, fuel heat value smaller fuel consumption will be more height of the fuel that has a high heat value [13],[17].

To determine the performance of the diesel engine, the required analysis data and discussion of data about the power, torque, and fuel consumption (SFOC) of the diesel engine when using diesel fuel pure (JME 00) and mix tends to Waste cooking oil Methyl Esther (JME 50) [11].

Durability: Engine manufacture did not test their engine product with alternative fuel. For that reason, we need to conduct a durability test of engines with alternative fuel. This test is done by knowing the effect of using alternative fuel toward components of diesel engines [13].

There are two ways of durability test, with on the road durability test and laboratory test. On the road durability test is the engine is running in a real condition with certain distances. As a result, it is exactly the same in the real. Laboratory tests are usually conducting in the engine testbed or chassis dynamometer. This test is following the engine manufacturing (EMA) standard. However, the engine has to operate with variable speed and variable load for certain times [13].

Durability Test Diesel Engines: Each Engine Manufacturing did not test the durability engine with alternative fuels, so if there is an alternative fuel, then the need for engine durability testing (test durability). There are two common ways in which the engine durability testing laboratory testing using the engine or chassis dynamometer testbed. Laboratory testing using the engine or chassis dynamometer test bed following the procedures provided by the Engine Manufacturing Association (EMA) [13][15].

The durability testing process is performed on a standard engine is Diesel Brand Dong Feng-type R-180. Before the first resistance testing is practiced blending techniques learned, which showed that mixing between JME and diesel fuel homogeneous mixture and can be used as diesel fuel with a diverse mix composition. Diesel engine start system bit experience change whereby when using diesel fuel, the engine very easy to start, but it is slightly different when the engine using a mixture of JME and diesel fuel, the engine start diesel a little bit of trouble as the operating time of 150 hours or more in which the diesel engine requires 2-3 times the process start [13]. It is also experienced by two researchers using sunflowers as methyl ester maker. The two researchers had difficulty at the time of cold start [19],[20]. Sunflower methyl ester cetane number having an index lower than the same diesel oil with fuel used in this durability test, namely Waste cooking oil Methyl Esther (JME), which has a cetane number index relatively lower than diesel is around 53. The difficulties during the process start the diesel engine on the injector 
because there are a lot of carbon deposits so that the fuel entering the combustion chamber is not experienced carburetion perfectly. This can be explained when the demolition machine then examined were found with the number of deposits that form on the injector nozzle, which is experiencing heavy deposit (the content of a deposit that much) on all nozzle fuel, deposits are formed in nature is very hard and requires a process scrap to clean [19].

Engine durability is very good; the engine can be durable in conditions share a kind, where the conditioning, according to EMA, consists of 4 stages. The low idle diesel engine is operated without a load where the engine speed is the minimum speed can live. This step is performed for 30 minutes. The high idle diesel engine is operated to the weight of $25 \%$ of the maximum torque, and speed was set at $90 \%$ of rated power speed. This step is performed for 30 minutes. Rated power diesel engine speed is operating at maximum speed in accordance with the specifications of the engine, and then the load is set at maximum load. This step is performed for 60 minutes. The peak torque speed operates the speed and load of the diesel engine when the maximum torque step is carried out for 60 minutes. By following the four steps above machine is not on track to meet rated condition phases and stages of peak torque, and fuel consumption of the two phases is not much different from diesel engines that use diesel fuel [15]. Diesel engines are used to test the durability is very durable and does not find it difficult to take a variety of road conditions, although there is little difference in fuel consumption [15]. The testing method used is the on-road durability test [13].

Damage Level: in order to evaluate the level of damage to the diesel engine, it has been observed visually and laboratory tests. Engine check-up is done by dismantling the machine and check the key components of the combustion system. Visual data major components such as pistons, cylinder head, intake and exhaust valves, and nozzle were also compared. From here, we see the difference. The lubricant also a comparison in testing the level of damage to the engine by looking at physical and chemical properties as well as metal elements contained therein, then we can compare the degree of damage to the machine [13].

After the check-up of the engine components, the durability test time with the biodiesel fuel is not at all give the problem component. The injector is in good condition even if the nozzle is no build-up of carbon deposits; however, the injector function properly [20][21].

Carbon deposits also measure as parameters even if the carbon composite component damage can be cleaned in a specific time period. Carbon build-up can be seen in the visualization or observation on the nozzle, piston, cylinder liner, and inlet and exhaust valve [13].

At the piston, the second piston surface showed a deposit formed. Deposit on the surface of the piston when the engine fuel use JME 50 looks to be 'wet' and the other with a look a little greasy pile deposit that shows when the engine using diesel fuel origin look more 'dry' [13]. Allegedly the characteristics of the fuel were affecting the appearance of the deposit on the surface of the piston. Unburnt fuel during a low loading is most likely that the deposit is formed. Where all piston show heavy deposits on the surface of the piston, all of these deposits indicate the nature of the wet and greasy when they use biodiesel fuel [13],[22].

The cylinder liner machine does not show signs of wear visually, but analyze lubricant showed that the cylinder liner when using JME 50 little experience corrosion and wear evident on the compounds formed $\mathrm{Fe}$, great value [13].

Deposit build-up on the cylinder head is pretty much invisible to the exhaust valve and fuel spraying area; when using fuel JME 50, it appears that the deposit formed more oily and soggy like on the surface of the piston. In contrast to the deposits, that form looks drier, and the deposit looks a little harder [13],[22]. Wet and oily sightings were allegedly derived from fuel JME, which has high water content, thus affect the nature of the deposit formed on the components joined the combustion chamber [13].

The level of damage to the diesel engine can also be seen from metallic elements that are worn. There are three kinds, namely, wear adhesive wear, wear due to corrosive wear, and tear due to dust (friction) [23]. Wear and tear caused by the adhesive layer of lubricating oil, corrosive wear caused by carbon deposits, moisture, and acids. Whereas the dust particles cause friction wear. In the case of this study, developed metal damage due to oil layer lubrication even exists but should not be compared because the second experiment using the same type of lubrication (variables held constant). Setbacks engine quality (especially in the combustion chamber is cylinder liner, piston, piston rings, cylinder head, valve, etc.) that can be distinguished are due to corrosive and friction. Both types of damage can be caused by fuel characteristics and combustion processes [15].

The element of metal contained in lubricating oils, in general, the metal contained in the lubrication like $\mathrm{Cu}$. $\mathrm{Cr}, \mathrm{Al}$, and $\mathrm{Pb}$ from fuels containing biodiesel produce smaller numbers. But others have the same numbers with a lubricant for diesel fuel are: $\mathrm{Si}$ and $\mathrm{Sn}$ are to $\mathrm{Si}$ has the numbers 0.2 and $\mathrm{Sn}$ have a figure of 0.01 . The only big more than metal is Fe. In diesel fuel, which contained $\mathrm{Fe}$ is $10.1 \mathrm{ppm}$, while in $\mathrm{JME}, \mathrm{Fe}$ contained was 10.4. Of the existing conditions, wear caused by corrosive is the most dominant due friction to corrosion caused by steam that comes to infiltrate the gap - the gap between a piston ring and cylinder liner, the notion is reinforced by a water content greater lubricating oil in diesel engines by using biodiesel as fuel and can be seen in the water content of $0.9193 \%$ [13].

The Viscosity of each lubricant using different fuels equally increased for used oil with diesel fuel at a temperature of $40^{\circ} \mathrm{C}$ was increased by $34.6 \mathrm{cSt}$ at a temperature of $100^{\circ} \mathrm{C}$, while an increase of $15.11 \mathrm{cSt}$, while for used oil with the fuel JME 50 at a temperature of $40^{\circ} \mathrm{C}$ was increased by $14.8 \mathrm{cSt}$ at a temperature of $100^{\circ} \mathrm{C}$, while an increase of $10.36 \mathrm{cSt}$. The increase in the Viscosity of lubricating oil is caused by the amount of lubricating oil evaporation that occurs. Besides, the additives that are maintaining Viscosity also have contributed to the increase in Viscosity [13],[24]. 
TBN (Total Best Number) of used oil showed the yield to the contrary. When using pure diesel engines, TBN of lubricants decreased by $0.4675 \mathrm{mg} \mathrm{Koh} / \mathrm{g}$, while using fuel when the actual 50 TBN JME value increases around $0.3769 \mathrm{mg} \mathrm{Koh} / \mathrm{g}$. The decline is caused by TBN lubricants react to neutralize the acidic nature of the oxidation products, TBN decreases the limit is $60 \%$ of the number initially if already exceeded that limit, lubricating oil is recommended to be replaced. While the increase in the value of TBN in the lubricant with fuel JME 50 suspected to be caused by the excessive alkaline nature of the fuel itself because in the process of making the addition of $\mathrm{KOH} \mathrm{JME}$ very alkaline so that these properties have contributed to increasing the value TBN [13], [32].

TBN (Total Base Number) Testing numbers total TBN is very important in the analysis of lubricant service life. TBN is a value that indicates the number of milligrams of potassium hydroxide is able to neutralize the acidity that occurs in one gram of lubricant. The new lube oil SAE B 40 has a TBN value of $10.26 \mathrm{mg} \mathrm{Koh} \mathrm{/} \mathrm{g.}$ Figures TBN in oil with diesel fuel is 9.7925 , while the lubricant with the fuel JME 10.6369 [13], [31].

The flashpoint of each lubricating oil is different. When using solar flash point rose about $23^{\circ} \mathrm{C}$ while when using JME 50 flashpoint down about $40^{\circ} \mathrm{C}$. This decrease is due to fuel dilution that effectively lowers the flashpoint of lubricant while the rise in flashpoint indicates the cooling water is mixed in the lubricating oil so that the effect is to raise the flash Point lubricant [13]. If you see a fairly high water content of each lubricant, the flashpoint test results do not indicate the actual figure, which the water content limit for testing a flashpoint that is worth is $0.5 \%$. The water content or the water content in each of the lubricating oil showed a very large, which in graph 4.9 exceeds the limit allowed. This is caused by water content in lubrication caused partly by condensation of water vapor in the crankcase, leakage of cooling water, and may also due to the length of time sampling the lubricating oil from the crankcase. If the sample is too long ignored in the crankcase before it is taken, then the condensation of water occurs when the engine cools after the operation. The length of time allowed for sampling is a maximum of 6 hours after the machine is operated [1], [24].

Levels of sulfur in the used oil when the engine using diesel fuel caused by the blow-by, which the entry of fuel into the crankcase lubricant. Characteristics of diesel itself contain the sulfur that caused the sulfur content of more than lubricating when using current fuel JME. Characteristics JME has very low sulfur content [13].

Ash, sediment content of each lubricant average is still below the maximum allowable standard, so the quality of lubricants for these two parameters still considered feasible to be used any longer [13].

Exhaust emissions: the result of a combustion process in the engine. Emissions contain various chemical elements such as $\mathrm{CO}$ (carbon monoxide), $\mathrm{C} 02$ (carbon dioxide), pm (particulate), NOx, hydrocarbon, and so on, which is clearly dangerous in life. Testing healthy by analyzing the existing parameters in air emissions consists of particulate matter (dust), sulfur dioxide (SO2), nitrogen dioxide (NO2), hydrogen chloride $(\mathrm{HCl})$, chlorine gas (CI2), ammonia (NH3), hydrogen florida (HF) and opacity [13].

The measurement results and 3-D CFD calculation results of the baseline engine were compared. Figure 2 shows the comparison of cylinder pressure curves of the engine under full load operating conditions [33].

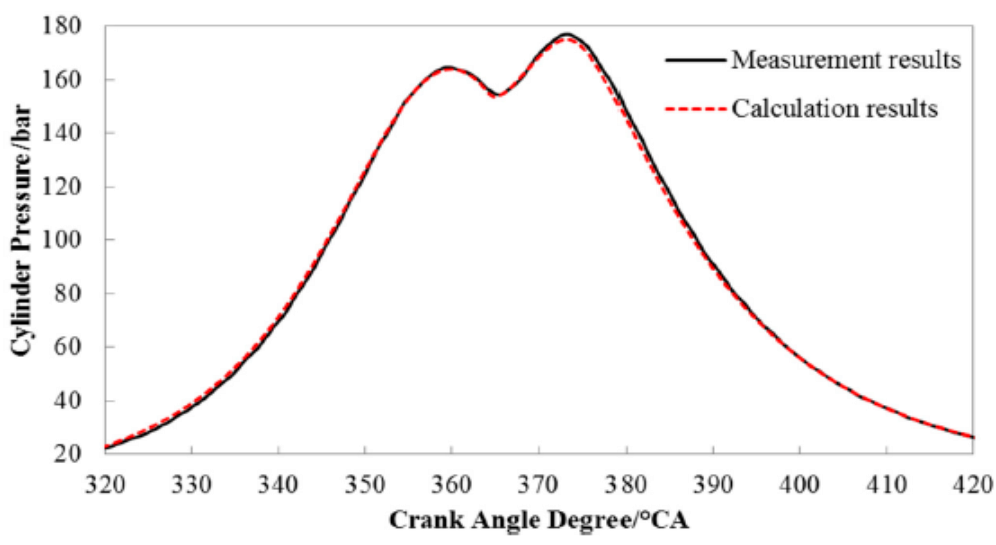

Figure 2. Comparison of measured and calculated cylinder pressure curves

As can be seen in the figure, the calculated data agree well with the experimental data. Meanwhile, the NOx emissions calculation was validated base on the NOx emissions data measured on the test bench. Table 5 lists the parameters of the NOx analysis used in the measurement, and Figure 3 presents the comparison of measured and calculated NOx results under test cycle type E3. The deviations of calculated results from measured results are smaller than $2.4 \%$. Based on the validation, other cases were calculated [33].

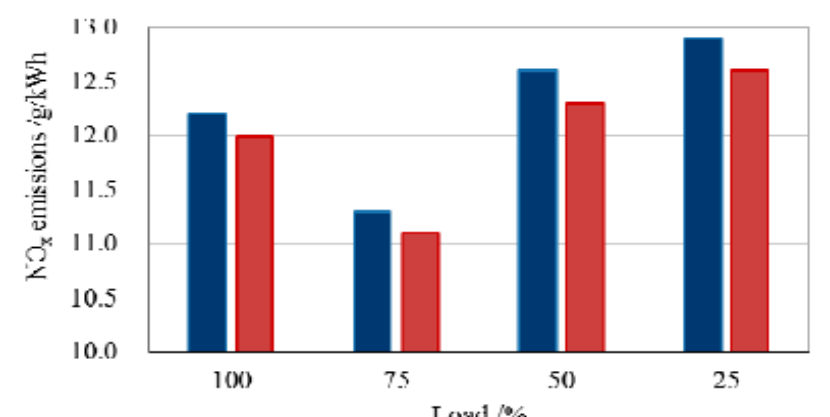


O Measured Results O Calculated Results

Figure 3. Comparison of a measured and calculated result of $\mathrm{NO}_{\mathrm{x}}$ emissions.

TABLE 5.

CAI, CALIFORNIA ANALYTICAL, INC. (ORANGE, CA. USA)

\begin{tabular}{ccccc}
\hline Manufacturer & Model & $\begin{array}{c}\text { Measurement } \\
\text { Range }\end{array}$ & $\begin{array}{c}\text { Span Gas } \\
\text { Concentration }\end{array}$ & Deviation \\
\hline CAI USA & CLD 600 & $0-200 \mathrm{ppm}$ & $1904.4 \mathrm{ppm}$ & $\leq 0.2 \%$ \\
\hline
\end{tabular}

According to various studies, biodiesel derived from waste cooking oil proved to be more environmentally friendly fuel than the results are known and used today. Nitrogen Monoxide emission levels (NOx) in the biodiesel from used cooking oil to produce emissions $12 \%$ lower than emissions produced by diesel oil [2],[19]. Another advantage, the exhaust emissions of the unburned form of carbohydrates produced biodiesel used cooking oil turned out to be $25 \%$ lower than diesel oil. Similarly, emissions of particulate matter (dust) produced cooking oil biodiesel, which passes $40 \%$ lower than diesel oil. Additionally, cooking oil biodiesel contains no sulfur so that the combustion is not generating emissions of sulfur dioxide. Fuel use, in one day, ten buses owned Trans Pakuan Bogor municipal government requires 100 liters of cooking because each bus filled 10 liters of used cooking (biodiesel) as a mixture of 50 liters of diesel or 1: 5. At a ratio of 1: 5emitting gray become whiter, while the use of $100 \%$ biodiesel used cooking produces exhaust emissions that spread the aroma of fried food [13].

Particulate Removing: particulate removing filter system uses a single-stage element. When contaminated fuel enters the vessel, particulate (rust, scale, dirt, and other contaminants) is removed, providing clean diesel to your engine and equipment (34).

Coalescer /Separator: coalescer /separator system consists of two elements, creating a two-stage filtration process. When contaminated fuel enters the vessel, articulate (rust, scale, dirt, and other contaminants) are removed, and water is coalesced by the first stage filter (coalescing is when the water droplets collect on the media and then fall into the sump to be removed). Any free water is separated by the second stage element providing clean, dry diesel to your engine and equipment (33) (34).

\section{CONCLUSION}

From the diesel engine durability test, performance analysis, analysis of the degree of damage is indicated by the metal content in lubricants, and test the properties of each lubricating. It can be some conclusions as "follows: Resilience diesel engine has not changed despite the use of fuel JME 50. A diesel engine is able to overcome the four stages of EMA in which each stage has a different load and rotation. The diesel engine does not degrade performance significantly of the maximum power, the maximum torque, and the SFOC. The maximum power of the diesel engine when using JME 50 has increased power by $0: 21 \%$. SFOC while at maximum power when the diesel engine using JME 50 was lower by $3.9 \%$. The torque is generated by the diesel engine level using JME 50 lower $8.8 \%$ but SFOC higher by around $9 \%$. The extent of damage the diesel engine is not too great because the stack deposit is high only found on the injector and the test results only the lubricant metal content of $\mathrm{Fe}$ is higher of used oil that uses diesel fuels, metals $\mathrm{Fe}$ indicates the cylinder liner a bit of wear, results of testing properties of the lubricating oil, the quality of good lubricant the only leakage of engine coolant system needs to be fixed because the used oil that has a high water content which is not good for further engine operation. According to various studies, biodiesel derived from waste cooking oil proved to be more environmentally friendly fuels than the results are known and used today. Nitrogen Monoxide emission levels (NOx) in the biodiesel from used cooking oil to produce emissions $12 \%$ lower than emissions produced by diesel oil. Another advantage, the exhaust emissions of an unburned form of carbohydrates produced biodiesel used cooking oil turned out to be $25 \%$ lower than on diesel oil.

\section{ACKNOWLEDGMENTS}

My gratitude goes to the ITS marine engineering lecturers, who have shared their knowledge and encouraged the realization of this paper

\section{REFERENCES}

[1] G. Abdul Somad, the effect of variations in the mixture of diese fuel and waste oil tire against the concentration of exhaust emissions in diesel engines,

[2] Zuhdi A. Asieanto, NOx reduction method permission slowdown in high- speed diesel engine, 1996

[3] Agus Purwanto "Biodiesel Feedstock Multi Effect Against Performance Diesel Engine - Thesis, 2014

[4] Anonymous. (2005). "Curcus Jatropha Plantation Development as A Source of Row material for Biodiesel" Directorate General Of Estate Crops, Jakarta.

[5] Purnomo, S., Yulianto, N. and Pasaribu, R., (2003). "Biodiesel from Coconut Oil" National Seminar Presiding Chemical Engineering Indonesia, Yogyakarta.

[6] Soerawidjaja,. (2006). "Biodiesel is the fuel of the engine / diesel engine consisting of alkyl esters of fatty acids" Palm Biodiesel Fuel on the performance and emission of the Automotive Diesel Engine ". Agricultural Engineering International: the CIGR eJournal. Manuscript EE 07 005. Vol. X.

[7] Bakhtir, A. (2003). "Biodiesel from oil Distance with Strong Bases" Proceedings of the Seminar and Process Engineering in 2003, Semarang. 
[8] Utomo, J., (2004). "The study of biodiesel production of oil with an acid-base catalyst" Presiding STNPK VI.

[9] Knothe, G.H. (2006), "Analyzing biodiesel; Standards and other methods Journal of the American Oil Chemists' Society, 83 (10): 823-833.

[10]I Wayan. Suirta, (2009) "Preparation of biodiesel from palm oil Waste cooking oil Ester", Journal of Chemistry 3 (1), Department of Chemical Science Faculty at Udayana University, Bukit Jimbaran.

[11]Zuhdi A. (2002), "Application Usage Waste Methyl Ester".

[12] Pramesti, L, M. Zuhdi F, Ariana, I M. (2013) "Analysis of Iodine Score Impact On Biodiesel From Waste Cooking Oil And Establishment Of The wear rate of Carbon Deposit On Small Parts Marine Diesel Engine" Presiding Graduate School, Institute of Technology, Surabaya

[13] Aguk Zuhdi MF and Wisnu Hakikim. The Effect of Used Waste Methyl Ester as Suplement Fuel to Durability of Diesel Engine, 2005

[14]Clement D.L, (1996) "Biodiesel Fuel Blending formulating Rules"., American Society of Agricultural Engineers Publication

[15]Zuhdi M.F.A (2003). "Biodiesel as Alternatives to Fossil Fuels In Diesel". RUT VIII energy, it will Surabaya Technology Division.

[16] Ahdiyat (1994), "Influence the quality of diesel fuel in the combustion process"

[17]La Puppung (1986), "The use of coconut oil as a engine fuel diesel"

[18]Fort E. F and Blumberg P. M (1997), "Performance Aand Durability Of A Turbocharged Diesel Fuelled With Cottonesed Oil Blend"

[19] Ingle, S ,. Nandedkar, V., Nagarhalli, M. (2002) "Prediction of Performance and Emission of Palm Oil Biodiesel in Diesel Engine IOSR" Journal of Mechanical and Civil Engineering (IOSRJMCE) Kopargaon 423 603, India PP: 16-20

[20]Zuhdi M.F.A, Gerianto I, Hashimoto M, Tomohisha D. (2002), "The Characteristics of Castor Oil as a Bio-diesel Fuel and its Effects on the Diesel Engine's Performance" Kobe University of Mercantile Marine (KUMM) - Japan.

[21]Fahruri, S (2003), "Experimental Study of Performance Diesel Fuel Using Waste cooking oil Ethyl Esther", Final Project of Marine Engineering Department - Faculty of Marine Technology ITS

[22]Baranesco R. A and Lusco J.J (1997) "Performance Durability And Low Temperature Evaluation Of Sun Flowe Oil As Diesel Fuel Extender"

[23] Havendri, A (2008) "Comparative Experiment Assess Performance and Emissions Diesel Fuel Using Solar mixture with Biodiesel CPO, Distance Oil and Coconut Oil" Journal Vol.1 Year XV 29 Department of Mechanical Engineering, University of Andalas.

[24]Garnida (2004) "Lubricants And Diesel Engine Lubrication', www.plnkc.or.id

[25]Zuhdi M.F.A, Gerianto, L, and Budiono, T., (2002) "and characterized the production of Bio-Diesel And Mechanical mixing with diesel oil (Gas Oil)" National Seminar on Theory Application Marine Technology 2002 FTK ITS

[26]Fahruri, S (2003), "Experimental Study of Performance Diesel Fuel Using Waste cooking oil Ethyl Esther", Final Project of Marine Engineering Department - Faculty of Marine Technology ITS.

[27] Hamid, T. and Hertanto, Y. (2003). "Preparation of Biodiesel from Coconut Oil" BARCO "Varying Number of $\mathrm{NaOH}$ " Proceedings of the National Seminar on Chemical Process Technology V

[28]Hanif (2004), "Achievement Test Engine Diesel Fuel Biodiesel as Alternative Fuels Journal R \& B Volume 4, Number 1 Lecturer Department of Mechanical Engineering, UNY.

[29] Purnomo, S., Yulianto, N. and Pasaribu, R., (2003). "Biodiesel from Coconut Oil" National Seminar Presiding Chemical Engineering Indonesia, Yogyakarta.

[30]Zuhdi M.F.A, Gerianto I, Hashimoto M, Tomohisha D. (2002), "The Characteristics of Castor Oil as a Bio-diesel Fuel and its
Effects on the Diesel Engine's Performance" Kobe University of Mercantile Marine (KUMM) - Japan.

[31]K.Svaramakhrisan, P. Ravikumar., Determination of cetane number of biodiesel and its influence on physical properties.

[32] MA Fazal, ASMA Haseeb, H.H Masjuki.," Investigation of friction and wear characteristics of palm biodiesel" Department of Mechanical Engineering, University of Malaya, 50603

[33]Liyan Feng Jiangpiang Tian, Wuqian Long, dkk, "Decreasing NOx of a low speed Two Stroke Marine Diesel Engine by Using In Cylinder Emission Control Measures" 2016.

[34]I.W Suirta, 2007," Preparation of Biodiesel From Waste Cooking Oil Palm".

[35]Evi Setyawati, Fatmir Edwar. (2012), "Technology Processing of Biodiesel From Used Cooking Oil By Microfiltration And Transesterivication Techniques As An Alternative Fuel Of Diesel Engine). Jurnal Riset Industri Vol. VI No.2, Hal 117-127.

[36] Muhammad Bismadver Budiman, Karsten Wehner, Steffen Loest. (2019). "Economy Analysis of Biodiesel For Agriculture Purpose of Indonesian Farm". IJMEIR, Vol. 4(2), 86-93. 